\title{
PERAN TEKNOLOGI DALAM MENGEMBANGKAN POTENSI DIRI BAGI SANTRI DI YAYASAN PEMBANGUNAN MASYARAKAT SEJAHTERA KELURAHAN KEDAUNG PAMULANG TANGERANG SELATAN - BANTEN
}

Ali Maddinsyah*, Irvan Fauzi, Akhmar Barsah

Dosen Ekonomi Fakultas Ekonomi Universitas Pamulang

Email*: alimaddinsyah@gmail.com

\begin{abstract}
ABSTRAK
Tulisan ini bertujuan memberikan pengetahuan kepada para santri tentang Teknologi adalah salah satu acuan yang dipakai untuk sukses, memberikan pengarahan kepada para santri tentang peran teknologi dalam pengembangan potensi dir serta memberikan pelatihan kepada para santri bagaimana cara mengembangkan potensi diri dalam bidang teknologi.

Metode yang dipakai dalam kegiatan pengabdian masyarakat ini adalah dengan metode pelatihan, seminar dan tanya jawab seccara langsung.

Sasaran yang ingin di capai melalui program ini adalah agar para santri Yayasan Pembangunan Masyarakat Sejahtera dapat menjadi SDM yang berkualitas, berkuantitas, serta unggul dalam di semua bidang .
\end{abstract}

\section{Kata Kunci: Teknologi, Potensi Diri, Sumber Daya Manusia}

\section{PENDAHULUAN}

Teknologi sendiri bisa diartikan sebagai suatu alat yang diciptakan oleh manusia dan bisa memberikan manfaat bagi manusia lainnya dengan harapan dapat memudahkan dalam melakukan suatu hal. Seperti penggunaan smartphone di masyarakat mulai dari anak sekolah hingga pegawai profesional.

Smartpanhone tersebut berfungsi mulai dari sebatas alat komunikasi, alat bersenang - senang seperti bermain game, social media hingga sebagai media yang mampu menghasilkan uang bagi pemiliknya yang menjalankan bisnis secara online ataupun untuk berhubungan dengan koleganya.

Tidak hanya sebatas itu, saat ini teknologi juga digunakan pada kegiatan perusahaan, baik dari sisi operasional maupun manajemen. Hal itu dikarenakan teknologi dapat membantu untuk mempersingkat waktu yang diperlukan dalam menjalankan pekerjaan dan juga untuk mengembangkan perusahaan seperti melihat perkembangan perusahaan lain yang menjadi Rival atau pesaing. Tentu saja itu semua tidak dapat terjadi dengan sendirinya tanpa adanya manusia yang melakukan input

Pada setiap prosesnya. Dari sisi manajemen penerapan teknologi misalnya dilihat dari sisi akuntansi yaitu, dahulu perusahaan menggunakan metode pencatatan berbasis kas (cash basis) saat ini menggunakan metode dengan basis 
akrual (acrual basis).Selain itu sistem akuntansi yang dahulu berupa single entry sekarang telah beralih menggunakan sistem double entry.

Dikarenakan sistem pelaporan single entry tidak dapat memberikan informasi yang komprehensif dan mencerminkan kinerja yang sesungguhnya. (Ariesta, 2008) Perubahan tersebut tentunya tidak dilakukan secara langsung, melainkan ada beberapa proses untuk dapat sampai pada saat ini. Dan hal itu tidak bisa diputuskan oleh karyawan dengan kinerja yang biasa saja tanpa adanya kemampuan pada bidang akuntansi selain itu informasi juga ikut berperan dalam pengambilan keputusan.

Hal itu bisa dikatakan sebagai akibat dari teknologi karena adanya perkembangan dalam pelaporan dan pencatatan akuntansi suatu perusahaan sehingga membawa dampak positif bagi perusahaan untuk terus melakukan perbaikan. Dan itu merupakan kecakapan pengelola dan pembuat laporan dalam mengikuti perkembangan teknologi saat ini. Dalam manajemen juga dikenal adanya sistem informasi manajemen atau biasa disebut dengan SIM. Pada umumnya sistem diartikan sebagai satu keseluruhan dari sejumlah komponen (bagian) yang saling berkaitan atau berhubungan dalam mencapai tujuan tertentu. Jika dihubungkan dengan manajemen, komponen tersebut adalah unsur-unsur dalam manajemen (perencanaan, pengorganisasian, pelaksanaan, penganggaran dan pengawasan) yang bergerak bersama demi mewujudkan tujuan suatu perusahaan. Selanjutnya yang dimaksud informasi manajemen adalah rangkaian kegiatan (manajemen) yang menghasilkan sejumlah informasi yang tersusun secara sistematik dan bersifat menyeluruh mengenai segala sesuatu di lingkungan suatu perusahaan. .

Berdasarkan penjelasan diatas SIM dapat diartikan sebagai kesatuan informasi mengenai kondisi SDM yang memiliki berbagai komponen berupa kondisinya di masa lalu, masa kini dan prediksi kondisinya di masa depan dalam lingkungan organisasi ataupun perusahaan. Sistem Informasi SDM tersebut berisi data seperti dokumentasi nilai yang dicapainya ketika mengikuti seleksi, hasil penilaian kinerja setiap pekerja dll. Selain itu juga berisi informasi mengenai karakteristik kepribadiannya, jenis dan tingkat keterampilan atau keahliannya, kemampuan manajerial prestasi kerja dan lain-lain yang di dokumentasikan secara individual. Dari apa yang telah dipaparkan paragraf sebelumnya, teknologi memiliki dampak positif pada segi keuangan (akuntansi) dan perkembangannya hingga saat ini. Pada sisi manajemen SDM teknologi juga mempermudah bagian HRD dalam melakukan penilaian dan penentuan kriteria pekerja secara cepat berdasarkan informasi yang telah diberikan oleh pelamar. Dan pada sisi produksi, pekerjaan beberapa abad lalu dikerjakan oleh tenaga manusia maka sejak munculnya revolusi industri sebagian pekerjaan dilakukan menggunakan mesin.

Siagian dalam bukunya yang berjudul Manajemen Sumber Daya Manusia (2014) mengatakan bahwa peranan mesin menjadi lebih besar dibanding tenaga kerja manusia. Sehingga terlihat bahwa ada dampak negatif yang ditimbulkan akibat dari perkembangan teknologi terhadap perkembangan SDM, contoh terdekatnya adalah kegiatan yang ada pada suatu perkantoran, kini jarang sekali menggunakan media "kertas dan pulpen" media tersebut saat ini digantikan oleh 
tinta printer, media penyimpanan data kini menggunakan flashdisk, hardisk ataupun media online seperti google drive. Sehingga tantangan utama yang harus dijawab oleh seluruh umat manusia di masa mendatang adalah peningkatan kemampuan untuk menciptakan organisasi yang lebih baik dan mengelolanya dengan tingkat efisiensi, efektivitas dan produktivitas yang semakin tinggi sebagai wahana untuk mencapai berbagai tujuan yang ingin dicapai. Tantangan tersebut muncul sebagai akibat dinamika manusia yang pada gilirannya membawa berbagai jenis perubahan, baik yang terjadi secara internal bagi organisasi maupun yang bersifat eksternal (P.Siagian,2014).

Pada Yayasan Pembangunan Masyarakat Sejahtera diperoleh data bahwa santri SD, SMP dan SMA yang ada di Yayasan Pembangunan Sejahtera kurang memiliki sarana dan prasarana teknologi karena keterbatasan dana Yayasan, sedangkan teknologi sangat diperlukan untuk semua santri agar mereka bisa sukses. Issu yang dihadapi saat ini adalah motivasi santri dalam mengembangkan diri dalam bidang teknologi terhambat dan tidak tahu bagaimana menggunakan perangkat computer yang notabene sangat penting bila mereka suatu saat bekerja.

Selain itu kondisi yang ada saat ini adalah (1) banyaknya santri yang merasa rendah diri karena kebanyakan santri berasal dari keluarga yang tidak mampu. (2) Hambatan biaya untuk melanjutkan sekolah menjadi kendala yang utama. (3) Semangat menjadi entrepreneur masih kurang. (4) Pengetahuan tentang pentingnya teknologi dan SDM yang berkualitas masih kurang. (5). Pengetahuan tentang dunia kerja juga masih rendah.

Oleh karena itu terbangunnya mindset, perilaku dan sikap santri menjadi benar, berkualitas dan lebih terarah sangat diperlukan yakni mampu meningkatkan kualitas SDM mereka terutama di bidang teknologi untuk menjadi yang terbaik di masa depan.

Ketika mereka lulus SMA mereka harus mampu menentukan pilihan untuk melanjutkan kuliah ke jenjang yang lebih tinggi atau mereka bekerja atau berwiraswasta.

Berdasarkan latar belakang di atas, kami dari Tim Pengabdian Kepada Masyarakat ( PKM) Universitas Pamulang (UNPAM) terpanggil untuk berbagi ilmu, berbagi kisah keberhasilan, berbagi motivasi, berbagi semangat kepada semua santri SD, SMP, SMA Yayasan Pembangunan Masyarakat Sejahtera dengan kegiatan yang dikemas dengan nama " Peran Teknologi Dalam Mengembangkan Potensi Diri Bagi Santri Di Yayasan Pembangunan Masyarakat Sejahtera Kelurahan Kedaung Pamulang Tangerang SelatanBanten ".

\section{TUJUAN PELAKSANAAN}

1. Memberikan pengetahuan kepada para santri tentang Teknologi adalah salah satu acuan yang dipakai untuk sukses.

2. Memberikan pengarahan kepada para santri tentang peran teknologi dalam pengembangan potensi dir . 
3. Memberikan pelatihan kepada para santri bagaimana cara mengembangkan potensi diri dalam bidang teknologi.

\section{KEGIATAN}

Kegiatan Pengabdian Kepada Masyarakat ( PKM ) ini dilaksanakan pada bulan Mei 2018. Sedangkan kegiatan pelatihan Pengaruh teknologi dalam pengembangan potensi dir dilaksanakan pada tanggal 29 - 31 Mei 2018 terhitung sejak prepare dan evaluasi kegiatan.. Sebagai lokasi kegiatan PKM dengan judul Peran Teknologi Dalam Mengembangkan Potensi Diri Bagi Santri Di Yayasan Pembangunan Masyarakat Sejahtera Kelurahan Kedaung Pamulang. Tangerang Selatan-Banten, bertempat di Jln. Mesjid Darusallam no.40 RT/RW 09/04 kelurahan Kedaung Pamulang -Tangerang Selatan.

\section{APLIKASI}

IPTEK merupakan suatu hal yang sudah tidak asing lagi dalam kehidupan masyarakat dewasa ini, seolah telah menjadi bagian primer dalam kehidupan manusia, karena hampir semua aspek kehidupan ini memiliki kaitan yang begitu sinkron dengan ilmu pengetahuan dan teknologi.

Seiring dengan berjalannya zaman, kedua hal ini berjalan begitu dinamis, seolah tak pernah ada habisnya, karena dari waktu ke waktu setiap orang selalu berusaha mengembangkannya, sebagaimana dapat kita lihat perkembangannya di Indonesia.

Pelatihan Manajemen SDM yang dilaksanakan di Yayasan Pembangunan Masyarakat Sejahtera diharapkan mampu membekali santri pelatihan dengan berbagai startegi dan tips bagaimana cara mengembangkan potensi santri / SDM agar dapat memahami teknologi yang berkembang pesat.

Pada sesi pertama sambutan dan doa oleh perwakilan yayasan, pada sesi pertama para santri diajak untuk melihat bagaimana perkembangan ilmu dan teknologi berkembang dengan pesatnya. Dan mengajarkan kepada para santri tentang pentingnya akhlaqul karimah yang terdiri dari sifat zuhud, sifat wara, sifat sabar, sifat tawadhu, atau rendah hati, sifat qonaah, sifat ikhlas, istiqomah yang sebaiknya dimiliki oleh semua santri untuk menghadapi perkembangan jaman.

Santri juga diharapkan dapat termotivasi untuk semangat belajar dan berlomba untuk mengembangkan ilmu teknologi. Diadakan pula sesi tanya jawab bagi semua santri serta games.

Kunci sukses yang pertama adalah setiap individu / santri harus mempunyai tujuan dan cita-cita, harus mempunyai harapan yang besar, berani untuk maju, berani menghadapi tantangan, berani berfikir positif, berani mempunyai tujuan besar, tetapi harus dilandasi tekad yang kuat.

Kunci sukses yang kedua berbakti kepada kedua orang tua karena banyak orang besar dan hidup sukses karena memperlakukan orangtua seperti raja. Dengan memberikan motivasi, wawasan dan pandangan untuk semua santri bahwa menghargai, dan menghormati orang tua yang telah membesarkan kita akan membawa keberkahan bagi kita. Keridhoan Allah ada pada keridhoan orang tua. 
Kunci sukses yang ketiga, yaitu menanamkan akhlaqul karimah pada semua santri. Akhlaqul karimah yang diajarkan didalam Al-Quran dan Hadis adalah sifat qonaah, sifat tawadhu, sifat zuhud, sifat wara, sifat sabar, sifat ikhlas, sifat haya, bersyukur kepada Allah akan membuat santri kita menjadi generasi penerus bangsa yang beriman soleh taqwa kepada Allah, jujur, adil dan juga bijaksana .

Pada sesi yang kedua santri mendapatkan siraman rohani, dan ilmu tentang motivasi dalam hidup yang sangat menyentuh hati para santri dan arahan untuk menjadi yang terbaik dari nara sumber TIM PKM mengupas tentang pentingnya manajemen waktu, bagaimana pentingnya efisiensi waktu, efektifitas kerja, bagaimana membuat percepatan aktivitas, belajar yang sistematis, terstuktur dan bagaimana memiliki jangkauan yang luas bagi semua santri bila mereka mengerti pentingnya teknologi. Diadakan pula sesi tanya jawab bagi semua santri serta games.

Pada sesi ketiga mengupas tentang bagaimana menumbuhkan minat para santri agar mampu menggapai cita-citanya . Menumbuhkan semangat pantang menyerah pada para santri, memberikan banyak contoh bila kita memiliki keyakinan kepada Allah dan memohon dengan sungguh-sunguh, berusaha dengan sabar dan giat pasti Allah akan memberikan jalan keluar dan memudahkan semua urusan kita baik di dunia maupun di akhirat. Diadakan pula sesi tanya jawab bagi semua santri serta games.

Pada hari kedua, sesi yang pertama, menjelaskan pentingnya memiliki manajemen karier, bagi semua santri agar cita-cita mereka dapat tercapai di masa depan. Diadakan pula sesi tanya jawab bagi semua santri serta games.

Sesi kedua mengupas tentang pentingnya produktivitas untuk santri sebagai generasi muda dan menjelaskan pentingnya ing bersyukur atas semua karunia yang Allah berikan kepada kita dan bagaimana menerapkannya di dalam kehidupan sehari-hari, serta menjalin tali silaturahmi yang baik bagi sesama muslim. Mengembangkan ilmu dunia dan akhirat ke arah yang positif serta bermanfaat bagi sesamanya umat. Diadakan pula sesi tanya jawab bagi semua santri serta games.

Sesi ketiga mengupas tentang menciptakan inovasi baru, melakukan banyak tebososan baru untuk meningkatkan kualitas dan kuantitas semua santri serta mengajarkan santri untuk berfikir out of the box , mengajarkan bagaimana mengatur pola pemikiran santri agar dapat melihat segala sesuatu hal dari beberapa sudut pandang. Diadakan pula sesi tanya jawab bagi semua santri serta games.

Sesi keempat mengupas tentang unsur kebersihan, kedisiplinan, keuletan dan menjaga kesehatan, menanamkan kesadaran kepada para santri bahwa kebersihan adalah sebagian dari iman, mendorong para santri untuk menjaga kebersihan tempat tinggal dan lingkungannya. Mengarahkan santri agar mengetahui pentingnya makanan yang bersih dan bergizi. Diadakan pula sesi tanya jawab bagi semua santri serta games.

Pada hari ketiga, sesi pertama mengupas tentang Strategi Pengembangan potensi dir, yang dapat mengiring pola pikir santri untuk berfikir kreatif. Banyaknya keterbatasan dalam hal materi bukan menjadi halangan bagi para santri untuk terus belajar. Strategi yang tepat dapat menghasilkan keberhasilan di masa 
depan. Memotivasi santri untuk belajar dan terus belajar. Memberikan arahan pada para santri bahwa keterbatasan dana dan fasilitas yang ada dapat diatasi dengan adanya bantuan dari pemerintah dan masyarakat . Diadakan pula sesi tanya jawab bagi semua santri serta games.

Pada Sesi yang kedua mengupas tentang pentingya memiliki keterampilan dan bagaimana cara meningkakan keterampilan bagi para santri. Keterampilan yang sebaiknya dimilki santri sesuai dengan bakat yang dimilki, memotivasi semua santri agar memiliki minat dan keterampilan . Diadakan pula sesi tanya jawab bagi semua santri serta games.

Pada Sesi yang ketiga mengupas tentang bagaimana menghormati, menghargai, serta berbakti kepada kedua orang tua karena dengan berbakti pada kedua orang tua membuat kita memperoleh rahmat dan keridhoan Allah SWT. Banyak orang besar dan hidup sukses karena memperlakukan orangtua seperti raja. Diadakan pula sesi tanya jawab bagi semua santri serta games.

Semua TIM PKM ini saling tolong menolong, saling membantu, bahu membahu memberikan sumbangan ilmu, pemikiran, sentuhan agama, serta kisah keberhasilan, pengalaman hidup semua anggota TIM PKM kita untuk para santri agar semua santri YPMS memiliki mental yang tangguh, saling menghargai satu sama lain, dan semua itu didapatkan melalui proses untuk mencapai suatu kesuksesan di dalam hidup.

Sebelum semua kegiatan berakhir kami TIM PKM memberikan informasi tentang Universitas Pamulang sebagai kampus terbaik pilihan santri, yang sukses membantu masyarakat untuk kuliah dengan biaya yang murah serta sesi tanya jawab bagi semua santri.

Berdasarkan dari survey terhadap santri yang hadir dan ikut dalam pelatihan, $100 \%$ punya keinginan untuk memperdalam ilmu pengetahuan dan teknologi. Perlu kita ketahui semua santri seusai lulus ingin menambah wawasan ilmu dalam berbagai bidang, dan melanjutkan ke jenjang yg lebih tinggi.

\section{METODE PELAKSANAAN}

1. Tahapan awal yakni survey pendahuluan. Pada tahap survey pendahuluan ini yang dilakukan oleh tim PKM adalah melakukan kunjungan ke lokasi, observasi, interview, dengan pihak Yayasan Pembangunan Masyarakat Sejahtera serta menganalisis kebutuhan sasaran PKM. Selanjutnya disusun program dalam bentuk proposal kegiatan.

2. Tahapan pelaksanaan yakni pelatihan Pengembanagn SDM dengan teknologi . Pada tahap ini semua kegiatan yang dilakukan untuk membantu menjawab dan memecahkan persoalan sasaran PKM, meliputi penyampaian materi kegiatan. 


\section{KESIMPULAN DAN SARAN}

\section{A. Kesimpulan.}

Berdasarkan hasil dan pembahasan kegiatan PKM tentang Pengaruh Teknologi terhadap Pengembangan potensi dir di Yayasan Pembangunan Masyarakat Sejahtera Kelurahan Kedaung Pamulang Tangerang Selatan, dapat disimpulkan bahwa santri mampu memahami pentingnya teknologi dan ilmu pengetahuan untuk menggapai cita-cita dan untuk sukses di masa depan. Santri mampu menentukan masa depan dengan menyadari potensi yang ada di dalam diri mereka, serta mengoptimalkan bakat dan kemampuan mereka.

Begitu juga santri mampu belajar menghargai diri dan lingkungannya, menyadari peluang yang akan mereka dapatkan bila terus belajar dan bekerja keras, sekalipun dari kalangan kurang mampu. Santri juga dapat memahami pentingnya memiliki Akhlaqul Karimah kepada kedua orangtua dan kepada sesamanya umat.

\section{B. Saran}

Saran yang dapat diberikan dari kegiatan PKM ini adalah :

1. Bagi santri mempunyai kesadaran akan tujuan dan cita-cita serta mempersiapkan diri untuk menjadi yang terbaik .

2. Bagi sekolah dan Yayasan perlu diadakan kegiatan seperti ini untuk memotivasi santri di awal santri masuk, di tengah, dan di akhir masa sekolah.

3. Bagi UNPAM adanya kerjasama yang terbangun dengan baik, agar terus berlanjut dan menciptakan inovasi baru agar menjadi kampus yang banyak berkarya dan berakhlaqul karimah.

4. Bagi TIM PKM teruslah menjaga kekompakan dan tali silaturahmi, serta banyak menebar kebaikan bagi sesamanya umat.

\section{DAFTAR PUSTAKA}

Gaol, Jimmy. L. 2014. A to Z Human Capital Manajemen Sumber Daya Manusia, Jakarta : Penerbit PT.Gramedia Widiasarana Indonesia.

Hasibuan, S.P Malayu, 2002, Organisasi dan Motivasi : Dasar Peningkatan Produktifitas, Jakarta : Bumi Aksara.

Sutrisno, Edy, 2014. Manajemen Sumber Daya Manusia, Jakarta :Kencana Prenada Media Grup. 


\section{DOKUMENTASI FOTO KEGIATAN}
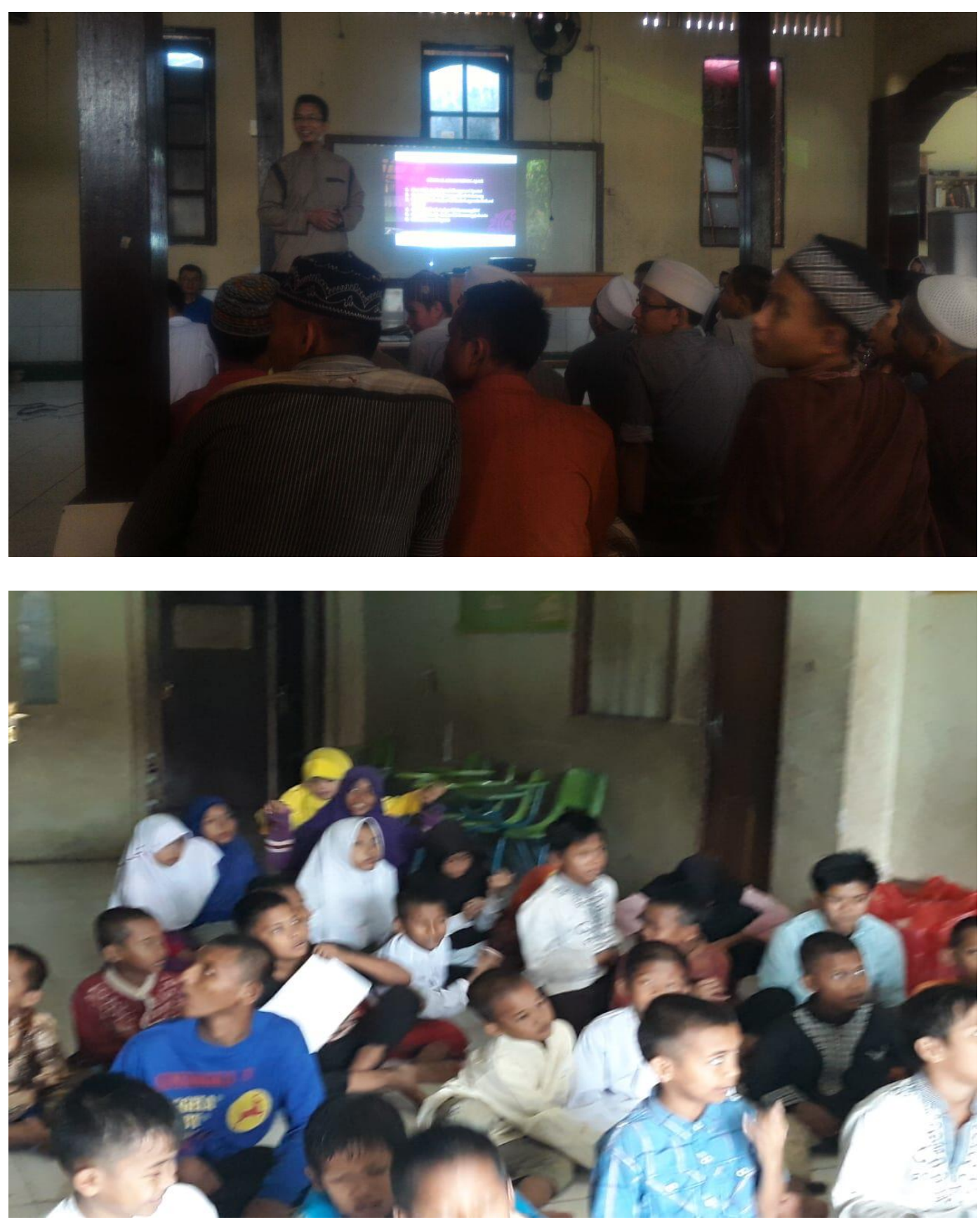